\title{
Gender Equality in the Inheritance Debate in Tunisia and the Formation of Non-Authoritarian Reasoning
}

\author{
Sari Hanafi \\ Professor of sociology at the American University of Beirut, Lebanon \\ sh41@aub.edu.lb \\ Azzam Tomeh \\ Researcher at the American University of Beirut, Lebanon \\ azzamtomeh@gmail.com
}

\begin{abstract}
This article discusses the debate on gender-equal inheritance in Tunisia. In it, Maeve Cooke's conception of authoritarian versus non-authoritarian practical reasoning is applied to see whether binaries, like religious versus secular, are existent in the public debate on equal inheritance in Tunisia. The mapping of the debate shows the existence of three sets of arguments: jurisprudential/textual, sociological, and legal. Proponents of equal inheritance base their arguments primarily on legal, then sociological, then textual grounds, whereas law opponents base their arguments on textual, then legal, then sociological grounds. The weakness of the sociological arguments of law opponents is evident when stating that a gendered division of labor within the family still exists without providing statistics or empirical evidence to back up that claim. Through shared categories and grounds, the discussions in Tunisia share a common language in the public sphere, allowing for the reduction of authoritarian tendencies and longstanding polarization through public deliberation.
\end{abstract}

\section{Keywords}

Tunisia - religion - secularism - gender equality - inheritance - non-authoritarian reasoning 
The Arab world has long been governed by authoritarian regimes, which encouraged a mono-culture in line with the official meta-narrative, driving other narratives to private and semi-private spheres. The absence of a Habermasian public sphere, necessary for intellectual cross-fertilization, has contributed to a deepening rift between large segments of liberals/non-Islamists/left and Islamists/Muslim democrats. The blame here is on both sides, though to varying degrees, not on the state or on a single side. It is accurate to say that since the outset of the Arab uprisings we have witnessed semi-civil wars between these political alignments, as is the case in Egypt, Syria, Yemen or Libya. Each camp has failed to understand the "other", seen as equally a domestic and external force. Acute dichotomies which try to reduce the liberal/non-Islamist camp to labels of modernist, secular, westerner versus the Islamists, conversely labelled as traditional, reactionary, and fundamentalist, would not account for the spectrum of current debates in the Arab world. These protracted sharp binaries have for decades produced identity politics that drove the contestation over the identity of the nation, and by extension, the format of its legislation. However, does the ongoing transition to democracy unsettle identity politics and facilitate a healthier debate? This paper will discuss the current heated debate about gender-equal inheritance in Tunisia, a country which has undergone democratic transition and witnessed a coalition between liberals and Muslim democrats (as Ennahdha [al-Nahḍa] labeled itself).

The saliency of the Tunisian revolution is due to its highly complex nature, not merely that it has been the catalyst for other Arab uprisings. Mūldī alAhmar (Mouldi Lahmar) sees its saliency stemming from it bringing down of an authoritarian regime that stifled liberties and disregarded rights and morals in the political context, as well as addressing the needs of "the dramatic historical articulation that took place between the social, cultural, political, moral and legal content of the demands of the protesters, and the changes which the Tunisian society witnessed at the level of rebuilding individual identities" (Ahmar 2014). The debate on equal inheritance was re-opened in Tunisia on the 13th of August 2018, when the president Beji Caid Sebsi (al-Bājī Qāiid al-Sibsī, d. 2019) declared his support for an equal inheritance law, in contrast to mainstream figh inheritance, which was summarized as males taking twice the inheritance of females when their parents pass away (Reuters 2018). This article examines the modes of reasoning used by proponents and opponents of

1 The authors thank Michael Avanzato for editing this article. 
the new law project through examining forty-one media statements offered by various Tunisian politicians, academics, and media figures since August 2018. Three research questions are the main concern of this article: What are the types of arguments raised to both support and oppose equal inheritance? How was religion navigated through public reason? Does the debate exhibit the persistence of identity politics and polarization between different elite formations in Tunisia or does it move towards a more peaceful and rational debate?

This article challenges many clichés, opposing the religious to the secular, and checks whether those binaries hold in the Tunisian context. We use Maeve Cooke's (2005) conception of authoritarian versus non-authoritarian practical reasoning as she construes "context" and "history" being what fundamentally distinguishes authoritarian claims from non-authoritarian claims. This is instrumental to the framing of our mapping and qualification of the public debate on the gender equality.

\section{Historical Framework: Liberties and Gender in Tunisia}

The statement of President Beji Caid Essebsi on the 13th of August, in support of gender equality in general, and equality in inheritance in particular came as a result of a historical pattern towards gender equality in Tunisia since the 180os. The Tunisian state, different from other states in the Maghrib, had a stronger, more binding social contract between the cities (as opposed to kinship based tribal organizations), and began deep reforms in the realm of state institutions, as well as educational institutions in the 1870 , leading to Sharía and human sciences being taught hand in hand in the Zaytūna and other state educational institutes (Charrad 2001). This laid the grounds for the reforms brought about by the Tunisian elite at the hand of modern Tunisia's founding father, Habib Bourguiba (al-Habīb Būrqïba).

Under Bourguiba, important changes in the Tunisian law occurred. In 1956, the Tunisian government changed the family code, banning polygamy and repudiation, and enforced equal divorce laws while promoting consensual marriage (Social Institutions and Gender Index 2014). This secularization process still associated itself with Islam. The constitution set by Bourguiba stated that "Tunisia is a free, independent and sovereign state. Its religion is Islam (al-isläm dinuhā), its language is Arabic, and its type of government is the Republic". It also stated that the president should be Muslim. However, reference in the constitution is also made to Tunisian customs ( $a^{\prime} r \bar{a} f$ ) which were used to justify banning polygamy while maintaining the inheritance law as is. 
Bourguiba publicly rejected both the state being ignorant of religion and the secular state model which solely depended on secular ethics as its legal basis (McCarthy 2014). Yet, Bourguiba's secularization was top-down which made the late sociologist Abdelkader Zghal qualify it as being 'mute' (Harmāsī 2012) and a style of "authoritarian reason", a term borrowed from Maeve Cooke as we will see. This is in line with much of the literature describing secularism as a state-to-society management, such as Asad's (2003) definition of secularism as the pre-management and intervention in religious life, or Agrama (2010) seeing it as an expression of the state's sovereign power, necessarily blurring the lines separating religion and politics. However, this claim is somewhat contentious. Bourguiba consulted with the Ḥanafì muftì Habib Belkhouja (al-Ḥabīb Ibn al-Khūja) on the reforms he wanted to enact. When Bourguiba asked Belkhouja for his opinion on equal inheritance, the mufti stated that the Qurannic verses were clear and decisive, and that inheritance is hence not amenable to ijtihäd (independent legal reasoning). However, Tunisians were allowed to allocate 30 percent of their wealth to whomever they wished in their will (wasizya). If they wanted to implement equal inheritance, they had to distribute their wealth while alive ('̄̄ 2017).

President Zine El Abidine Ben Ali (Zīn al-'Ābidīn Bin 'Alī, d. 2019) generally maintained the status quo on laws pertaining to religion. He focused more on the political domination of the religious field, as opposed to secularism (see for instance Īsā 2018, 72-78). It was only on the 13th of August 2017, on National Women's Day, that President Beji Caid Essebsi suggested that equal inheritance laws be legislated in Tunisia. This was based on a report issued by the Individual Freedoms and Equality Committee, a committee created one year before by the President to reform the laws of Tunisia to conform to the postrevolution 2014 constitution, as well as to international conventions (Grewal 2018). The report produced by the committee uses mixed research methods in its work, including participatory approaches, consultations, statistics and in-depth interviews.

The creation of this Committee triggered much contention in Tunisian public circles. It was accused by the second largest Tunisian political party, Ennahdha, of being of a single political domination, excluding more conservative circles from its work (France 24 Arabic 2017). This committee was composed of nine jurists and civil rights activists with a gender parity (four women, five men); two thirds of the committee are actually university professors. ${ }^{2}$

2 The committee members are:

- Boshra Belhaj Hmida (Bushrā Balhāaj Ḥmīda): A Tunisian lawyer, civic activist, and a member of the Assembly of the Representatives of the People. She is also a founding member, and then the president, of the Tunisian Association of Democratic Women. 
However, the committee excludes Islamic jurists from the Zaytūna University and experts close to Ennahdha. It should be noted that historically Tunisian society is divided into different elite formations that lead three communities: first, a francophone community (a sort of bourgeoisie); very fascinated by France and the West in general; second, a larger traditional community closer to Zaytūna, and finally, a tribal community in rural areas. Not only does each community have its own socialization and cultural references, but also its own way of distributing inheritance. The bourgeoisie had their men and women inherit equally, the traditional circles referred to mainstream Islamic inheritance, and the tribal communities generally did not allow women to inherit (Harmāsī 2018). Despite such divisions, the Tunisian historian Abdelhamid Hénia ('Abd al-Hamīd Haniyya) (Hénia 2015) highlights the emergence of individualism gradually in Tunisia, even prior to the emergence of the Tunisian state, which allowed for practices that surpassed tribal brotherhood in colonial times and social practices that transcended collective constraints.

- Kerim Bouzouita (Karīm Būzwìta): A doctor of Anthropology, and an international expert in strategy and advocacy at the United Nations. He is a professor at the Political School of Tunis and the Higher School of Economics.

- Abdelmajid Charfi ('Abd al-Majīd al-Sharfî): An Islamologist and author of several books on classical and contemporary Islamic thought. He's a member of the Higher Authority for Realization of the Objectives of the Revolution, Political Reform and Democratic Transition.

- Slim Laghmani (Salīm Laghmānī): Professor of Public Law and Political Science at the Faculty of Juridical Science in Tunis, and the director of the research laboratory "European Union Law and Maghreb Europe Relations" from 2001 to 2013.

- Salwa Hamrouni (Salwā Hamrūnī): Associate lecturer in public law at Carthage University, and a specialist in international human rights law and constitutional law. She was a member of the drafting committee of the Constitutional Court Act, and a consultant with national and international organizations including UNESCO, UNDP, and Lawyers without Borders.

- Slaheddine Jourchi (Salāh al-Dīn al-Jūrshī): A writer and activist, and president of the National Civil Council and vice-president of the Tunisian Human Rights League, as well as a member of $\mathrm{Al}$ Jahedh Forum.

- Iqbal Gharbi (Iqbāl al-Gharbī): Director of the Chair of Anthropology of Religion at the Higher Institute of Theology and Center for Pedagogical Innovation at University of al-Zaytūna.

- Malek Ghazouani (Mālik al-Ghazwānī:Vice-president of the Tunis Court of First Instance.

- Dora Bouchoucha (Durra Būshūsha): Professor of English literature and a film producer. She is the director of the Carthage Film Festival, and was president of production support commissions in France. (Committee on Individual Liberties and Equality n.d.) 
This article attempts to delineate the arguments on the law for equal inheritance presented in public to different audiences through media portals, including television and social media. Sixty-three arguments were extracted from forty-one randomly chosen media pieces from YouTube, Facebook, television channels, and other news portals online, from which forty were against the law of equal inheritance, two entries were neutral on the law, and twenty-one entries were for equal inheritance. The number of entries was reached through covering the major statements issued by party representatives, civil society, religious scholars, activists, academics, and protestors in the streets of Tunisia; specifically those covered by important news channels, and after that, those issued through Facebook and blogposts.

The number of media statements against the law being almost double those in favour of the law has to do with the nature of Tunisian society; and that since the majority of society is actually conservative, those speaking against the law, be they sheikhs, political activists, or people in the street are bound to outnumber those who support the law, namely a section of the Tunisian elite.

This article mainly focuses on statements made in the public sphere to the general public, not intellectual writings confined to intellectual circles. Academic studies and papers are not included in the content analysis.

As a framework, we will discuss the relationship between public reason and religion through Jürgen Habermas and Maeve Cooke, to show the tensions gravitating between dogmatism and open-mindedness, and between shutting down the public sphere from debate, and opening it to a variety of valid opinions.

As we said before, there are many clichés concerning labeling some geographical regions as religious or secular that are used to analyze the different intellectual traditions, popular religions, and institutional carriers that have produced different forms of religion and religiosity in contemporary society. In sociological debates, it is important to specify the place of religion in democracy and the public sphere. Citizens should be allowed to justify their political convictions in line with their religious ones, despite what John Rawls (1993) advocated. Habermas (2008), unlike Rawls, acknowledges the place of religion in the public sphere, but confines it only to informal deliberation and excludes it from the institutionalized form. He argues that religious communities must 
engage in hermeneutical self-reflection in order to develop an epistemic stance toward the claims of other religions and world-views, toward secular knowledge, especially scientific expertise, and toward the priority of secular reasons in the political arena (Walhof 2013, 229). But is it indeed possible to disentangle "religious" reasons from "secular" ones? Scholars such as Darren Walhof (2013), who studied the debate of the same-sex marriage in USA, rightly pointed out that "theology, politics and the identity of a religious community are all tied up with each other, as religious leaders and citizens apply and reformulate their theologies in new political contexts" (Walhof 2013, 229). Maeve Cooke (2006) states that the problem of religious positions is that they tend to be authoritarian and dogmatic in their formulation. Habermas, on the other hand, thought the problem was that they appealed to a single non-shared framework. However, if non-authoritarian arguments are formulated by religious actors, in which positions are not taken as absolutes, but are subject to argumentation, then those arguments can be translated into the public sphere without jeopardizing the freedoms and democracies necessary for its existence. A different way to attain non-authoritarianism could be the attempt to integrate secular and religious knowledge in a single framework, in which both sets of knowledge are understood in light of one another. The attempt of religious people to reconcile their worldview with the findings of science, and/or justify them using science, is an example of this. This would allow religious people to retain the certainty they find in faith (which can be subject of $i j t i h \bar{a} d$ ), and to engage in a public dialogue in which both the secular and religious languages are integrated into one worldview (Aduna 2015).

This opens the possibility to go beyond binaries of religious versus secular: the former associated with backwardness and irrationality, and the latter embodying rationality and a liberated mind, especially when it comes to gender issues. Feminists for example tend to be labelled as being secularists, as opposed to religious. Rare are the voices such as Saba Mahmood (2011) or Line Nyhagen (2017) who argue that feminists who worked to reform religious traditions from within reject the idea that religions are by necessity patriarchal. Islamic feminists, such as Fatima Mernissi (Fāṭima Marnīsī), Alaa Murabit (Alā’’ al-Murābiṭ), Neila Sellini (Nāyla al-Sallīn̄i), and Amel Grami (Āmāl Qarāmī) have made significant advances towards gender equality despite remaining obstacles and challenges. ${ }^{3}$ In the same vein in 'the West', scholars such as Joan Scott (Scott 2017) question the long-held assumption that gender equality is an enduring principle of secularism by arguing that it has been used to justify

3 In this regard see the excellent forthcoming paper of Hosn Aboud that was presented in the Workshop “Reconstruction of Islamic Studies" (American University of Beirut, 2018). 
claims of white, Western and Christian racial and religious superiority, and has served to distract attention from persistent difficulties related to gender differences. In addition, the inclusion of religion in the public debate on gender constitutes a major issue at stake. Line Nyhagen (2017) rightly distinguishes between three types of feminism: "A hard secular feminist stance views religion as a patriarchal system of institutionally determined beliefs and practices that are enforced by powerful religious authorities and 'copied' by adherents who suffer from 'false consciousness." Second is the mixed 'hard and soft' secular feminism that "view[s] secularism as necessary for gender equality and rejects the role of religion in the public sphere ... [but] it accepts that religious faith provides 'authentic' meaning in the lives of individuals." Finally, the soft secular feminism that "accommodates the role of religion in both the public and private spheres" (Nyhagen 2017, 499).

If we admit after Nyhagen that the issue of debates in the public sphere is not simply one of secular versus religious, we can move to another conceptualization of the issue, debating individualism versus familialism: those who consider that individual rights supersede collective rights, and those who believe in the family unit and the division of labor within it. ${ }^{4}$ In this respect, Cooke's (2005) conception of authoritarian versus non-authoritarian practical reasoning will be helpful to frame our mapping and qualification of the public debate on gender equality concerning the inheritance debate in Tunisia. Cooke states that there are several assumptions that govern that debate, and those include the assumption that: "there are no authoritative standards independent of history and socio-cultural context that could adjudicate rival claims to validity, especially in the areas of science, law, politics, morality and art" (italics ours) (Cooke 2005, 380).

Once those assumptions are present, Cooke states that considerations of "context" and "history" are what fundamentally distinguish authoritarian claims from non-authoritarian claims. Cooke (2007) also provides more specification to what would be authoritarian practical reasoning, highlighting two interrelated components on knowledge and justification: first, when knowledge-access is restricted, either because it is only accessible to a privileged group of people, or because its standpoint is removed from history and context (epistemological authoritarianism); second, when the justification

4 This debate is not only taking place in the Arab world but even in a very secularist country like France. A debate on adopting children by LG вT couples, as well as foster mothers are bringing controversies and protests to the street. Protestors have denounced "familyphobia" policies (see for instance www.theguardian.com/commentisfree/2014/feb/o7/ french-march-safeguard-family-values-gay-marriage). 
separates the validity of propositions and norms from the reasoning of the human subjects onto whom those propositions and norms apply (ethical authoritarianism). ${ }^{5}$ While those two components are essential in de-totalizing an argument, the assumptions which frame the public sphere are essentialized by Cooke, who is modestly skeptical of whether such components are fully applicable in a non-Western context.

In a more legal context, Ronald Dworkin's concept of law within a liberal democratic state is useful in thinking of authoritarian versus non-authoritarian reasoning (Dworkin 1985). Dworkin states that there are two ways of conceptualizing law in a civic state: the rule book conception and the rights conception. The rule book conception takes rules to be goals in and off themselves, and the spirit of the rule book as a determiner of new rules. Historical readings of the constitution, he states, are an example of that, where the intentions of the writers of the constitution in the US are taken to determine what the constitution means. Hence, statements like 'All men are created equal' mean all white adult land-owning males. The second conception of law according to Dworkin is the right conception, which frames rights in terms of the universalizable liberal values of individual freedom and equality. Under such a conceptualization, rules are read as an enforcer of those rights, and new rules are to be created only if they align with said rights. Under such a conceptualization, statements like 'All men are created equal' is understood to mean all human beings.

Dworkin then devises a useful tool of understanding law, which is the distinction between legal principles and legal rules. Legal principles are the underlying factors and variables which control the production of law, and take into account history, context, social conceptualizations of justice, individual rights (as a moral entitlement), and many other variables. Legal rules are specific verdicts which judge a certain action in a certain context, generally applied in an all-or-non manner. Dworkin states that legal principles should always be kept in mind when rules are being created and should cater for the preservation of those principles. With those two variables, Dworkin creates a two-fold protection of the individual, centering the production and reading of laws as revolving around rights (Dworkin 1978). Dworkin in fact invites us not

5 To make it clearer, epistemological and ethical anti-authoritarianism are linked by the ethical idea of autonomous agency: this agency can make descriptions, interpretations and normative projections contestable and that contestability requires the reasoning of concrete human agents (in historically specific socio-cultural contexts) which can be attributed to the ethical intuition that the freedom of human beings consists of important measures in the freedom to pursue their conceptions of the good on the basis of reasons that they are able to call their own (Cooke 2005). 
only to contextualize the law but to have moral principles on the legal reasoning and this is in line with Cooke's claim.

In looking at Islamic jurisprudence in particular, Mohammad Fadel (2007) has claimed that while Islamic laws can be integrated into the public sphere, some specific rulings are reasonably problematic. ${ }^{6}$ However, many of those can be re-integrated into the public sphere through the use of public reason itself. Fadel (2007) discusses the issue of inheritance explicitly. He alludes to Fazlur Rahman's notion that verses of the Qur'ān are not eternally binding, but are to be viewed as adjustments to the status of women in a certain time and place, and that since the Qurān emphasizes fundamental equality between men and women, the argument for equal inheritance is plausible. However, a case for the accommodation of a law of voluntary traditional inheritance can be made for two reasons: (1) It allows the actor to look out for their rational self-interest, avoiding sin, and (2) it prevents the use of coercion to impose one view of the good over another. Fadel's argument allows for a conception of inheritance laws that is neither totalitarian nor textualist.

Proponents and opponents of equal inheritance have referred to three sets of arguments: jurisprudential/textual, sociological and legal.

In the Report of the Committee on Individual Liberties and Equality, the issue of equality is appealed to through several arguments. The first set of arguments is jurisprudential, appealing to the higher objectives of Sharī'a (maquassid al-Sharía):

- The Qurān emphasized the equality of men and women in numerous verses. However, they traditionally had different rulings with their differing social roles. Since they have the same social roles now, they should have the same rulings, affirming original equality.

- Inequality between men and women is similar to slavery. Just as the former was rejected in light of the higher objectives of Sharita, so should the latter.

6 Fadel stated that those rulings which provide the grounds for a clash between public reason and Islamic rulings are: "(i) permissive rulings (permission to be polygamous, permission to own slaves), (ii) mandatory rules with which voluntary compliance could be consistent with the requirements of public reason (for example, Islamic inheritance law); and (iii) mandatory rules that are categorically repugnant to public reason (for example, the criminalization of apostasy)" (Fadel 2007, 6). 
- Inheritance does not fall under ritualistic acts of worship ('ibādāt). It's a worldly matter systematized by religion (mu'ämalāt), and thus should be subject to worldly reconsiderations.

The committee states that equal inheritance is in line with the conditions of the times in which we live, as well as the higher objectives of Sharîa.

The second set of arguments is sociological:

- The report states that socio-economic changes occurred in Tunisia over the past decades. Women are a major participator in the education sector, reaching $63.5 \%$ of the students in public education, and have strongly entered the workforce. Women have also become the breadwinners in many households. Since the status and role of women has changed, so should the rulings which are based on that status and role.

- Inheritance regulations are determined by: (1) relational proximity to the deceased individual, (2) the location of the inheritor, (3) the material and moral obligations of the inheritor. Those three transcend the sole element of gender. More variables must be considered. While there are cases where women inherit more than men, cases where men inherit more than women form $80 \%$ of inheritance occurrences in Tunisia.

The third and final set of arguments presented in the report take a legal perspective, based on the texts of the constitution and international agreements that support equality between men and women. Some legal texts mentioned may be ambiguous, but the point made is that there is substantial legal ground to complete gender equality. Thus, for legal consistency, inheritance laws should be adjusted.

In examining the three sets of arguments propagated by political actors who support and oppose the report, different arguments were proposed, and they will be divided, along the same lines, into: (1) legal arguments, (2) jurisprudential/textual argument, and (3) sociological arguments.

\subsection{Legal Arguments in the Public Debate}

In this section, legality will be analyzed based on Dworkin's (1978) variables of specific rules and principles. This section will examine how legal arguments move between legal literalism focused on rules (literalist appeals to international conventions leading to a concept of equality as a decontextual absolute value) and appeal to legal principles which account for the social context. Legal arguments reflect the conceptual and value-based debates that arose in the process of developing both sides of the argument.

The five main legal arguments provided by both sides were: the interpretation of the constitution, the implementation of international conventions, the tasks of the Committee, the nature of the civil state, and the nature of equality. 
Firstly, law proponents stated that since the Tunisian state is a civil state, and the reference for inheritance laws is the Code of Personal Status (CPS, Majallat al-Ahwāl al-Shakhșiyya), religious laws are not to be imposed. (Ten TV 2018) This contention points to the debate over the identity of the state; a debate which has permeated the Tunisian political scene since the revolution. The post-Revolution Tunisian Constitution of 2014 attempted to navigate the relationship between religion and state. It stated that the Tunisian state is a civil state. Nowhere did it mention that the source of legislation is Islam. The 21st Article of the constitution states that men and women should have equal rights and responsibilities ${ }^{7}$ (France 24 Arabic 2017; MedirTV 2018; Mosaique FM 2018).

Opponents of the law refer to the preamble of the constitution which states that Tunisia is a Muslim country, ${ }^{8}$ and the first article which states that Tunisia's religion is Islam. ${ }^{9}$ Legal arguments over equal inheritance reflect the tension between and ambiguity of these different articles. This is where the voluntariness of the law is important. Voluntary inheritance laws allow some citizens to follow figh law, and those who do not wish to follow that law are given the freedom not to do so. This was an argument used by several actors advocating the law (Sky News Arabia 2018; Ten TV 2018). However, problems arise when inheritors disagree over the method of allocation of inheritance; some wanting equal inheritance and others requesting Islamic inheritance. The law in this case states that equality takes precedence, hence having referential superiority over the Islamic inheritance.

The second legal argument is about the implementation of international conventions. Tunisia is a signatory of CEDAW, the Convention on the Elimination of All Forms of Discrimination Against Women, which makes the case for equal inheritance to be an obligation of the state (France 24 Arabic 2017; Mosaique FM 2018). In addition, in 2014, Tunisia revoked all reservations on the CEDAW agreement (FIDH 2014). This strengthens the case for Tunisia's international legal commitment to equal inheritance, and that the law should be adjusted accordingly.

The third argument concerns the tasks of the Committee on Individual Liberties and Equality. Law opponents assert that the Committee was assigned

7 Article 21: All citizens, male and female, have equal rights and duties, and are equal before the law without any discrimination.

8 The Preamble of the Constitution states: "Expressing our people's commitment to the teachings of Islam and its aims ..."

9 Article 1: Tunisia is a free, independent, sovereign state; its religion is Islam, its language Arabic, and its system is republican. 
the task of evaluating laws and determining which ones are in line with the 2014 constitution and the international commitments of Tunisia. It was not assigned the role of legislating and proposing new laws. The action the committee took, by drafting a new law, is not within its scope. This means the whole proposal of the law is unacceptable (Bū'ushba 2018).

The fourth argument is about the nature of the civil state, and whether grounding the laws in religion goes against the notion of a civil state. If so, how is the civil state defined? If it is by what the majority wants, then that leaves room for the interference of religion in the public sphere through the majority's vote (al-Jazeera Live 2017; al-Nahar TV 2018). If this is not the case, then secularized laws need to be enforced by the state regardless of what the people want, a point argued for by many proponents of equal inheritance (ввс News 2018; Sharaf al-Dīn 2017; Kapitalis Anbā' Tūnis 2018). Hence, legally-pluralistic voluntary inheritance laws seem more plausible in this case, compared to enforced Islamic inheritance or enforced equal inheritance laws (Sky News Arabia 2018).

The final argument was about the nature of equality. Does equality mean equality of opportunity, or equality of outcome, enforced by the state in order to decrease the wealth gap? It has been argued, for example, that reducing income inequality in Tunisia is more important than promoting equal inheritance (al-Jazeera Live 2017), as equal inheritance laws presume the presence of wealth in certain families, which is not the case in many rural and more impoverished areas in Tunisia. However, this argument, as previously argued, can be seen as a red herring, as the government can work on multiple fronts simultaneously. As one can see, the concept of equality was discussed more by the law's proponents as a legal ruling that should be enforced, and not as a legal principle that should be contextualized, and as a standard that takes into account Dworkin's concept of legal principles, well-situated in societal conceptions of justice and morality.

\subsection{Jurisprudential/Textual Arguments in the Public Debate}

Similar to the legal arguments above, Dworkin's distinction between legal rulings and legal principles can be applied in the religious context. There are four main jurisprudential/textual arguments provided by both sides: the interpretation of religious texts, the scope of Maqāsid al-Sharîa, Islam's improvement of the status of women, and finally that men do not always inherit more than women.

The first argument is about the interpretation of religious texts, provided for and against the law of equal inheritance. It can be split into two types: textual 
and philosophical. Textual arguments tend to lack flexibility and follow a single line of reasoning: "The text says so, therefore it is so." This argument was the most common for law's opponents, be they religious scholars, political activists, or people in street demonstrations (al-Jazeera Live 2017; al-Nahar TV 2018; France 24 Arabic 2017; Ḥamrāwī 2017; Ten TV 2018).

However, the problem with this argument is that it doesn't account for history and context, as per Cooke's measures, or for legal principles, as per Dworkin's analysis. This negates any chance for the accommodation of differing opinions, and splits the public sphere into orthodoxy and heresy, allowing for the elimination of other sides by virtue of their opinion itself, not their arguments. This form of argumentation translates itself on the other side with idealist absolutism, also devoid of history and context.

The second argument concerns the scope of Maqāssid al-Sharīa. Proponents of the law attempted to circumvent the objection to the law through the claim that religious rituals are unchangeable, but religious worldly dealings are. These arguments, advanced by those in favor of the law, had to be supported by referencing the Islamic tradition and Maquassid al-Sharî́a. This marked an important transition in the secular movement in the Arab world, from demonizing religious discourse to engaging with religion in order to develop arguments that allow the law's supporters not to be viewed as heretical. Another argument provided by those in favor of the law is a reference to the verse "And due to the wives is similar to what is expected of them, according to what is reasonable" (Q 2:228) (Rașif 22 2017). Other verses which emphasize equality were cited to prove that while gender equality is absolute, the inequality in the religious law historically was contextual.

The third argument concerns Islam's improvement of the status of women. Islam's contributions were used in defense of Islamic inheritance laws, and include the observation that Islam came and improved the status of women at the time of the prophet Muhammad. This came in the form of guaranteeing inheritance after women were deprived of it, preventing the infanticide of women, and allowing women to become active members of society (Bin Hasan 2016). The problem with such an argument is that it is historically stagnant, and presumes that history is not progressive, which violates one of Cooke's assumptions for the foundations of the public sphere.

The final argument stated is that men do not always inherit more than women. It was stated by several defenders of Islamic inheritance laws (alNahar TV 2018; Bin Hasan 2016). However, this argument was addressed by the Committee's report. While the Committee did acknowledge that there are 
specific instances where men do not inherit more than women, it is far more often the case that they in fact do.

\subsection{Sociological Arguments in the Public Debate}

The tremendous social transformation of the role of women under the effect of their education and work (Sharāra Bayḍun 2007), the crisis of masculinity (Daîf 2012) and youth-led mobilization (Kandiyoti 2004) have facilitated rethinking gender equality and female empowerment in Arab societies. There are three main sociological arguments provided by both sides: gender law and the nature of the Tunisian family, lack of equal representation in the Committee, and priorities within the Tunisian context.

Concerning the first argument, the purpose of equal inheritance laws according its formulators is to adapt to the changing gender roles in Tunisian society. A claim has been made that the law itself will further lead to a change in gender roles (al-Jazeera Live 2017). This was seen as leading to the "destruction of the traditional Tunisian family" (Bū'ushba 2018; Ennahdha Party 2018). This argument would seem valid were it not for the exaggerations in the language used, and/or supported by statistics or social research. However, with gender roles already changing in the Tunisian society, the case that this law could bring about a historical rift and a destruction of the family unit seems quite weak.

The Committee's report, as previously mentioned, stated that $54 \%$ of women are educated, compared to $46 \%$ of men, and that women are becoming more active in rural and urban areas, and increasingly participating in education and work. The utilization of statistics in this argument provides it with more weight. However, the statistics do not take into account the social class of those working women, their age, beliefs, roles in the household, and other variables into which the data could be broken down to, and which would provide a higher resolution description of the issues at hand. This multivariate reviewing of the same statistics may lead to a different analysis to the univariate description provided by the report to prove its point.

One of the noticeable matters in the inheritance debate is the absence of a political aspect to the debate, or at least it being minimal, with the arguments limited to representation and prioritization. The second argument thus is about the lack of large representation. A representative of Ennahdha movement stated that the Committee which wrote the report is of a single political orientation, namely secular, and therefore the report is biased in its representation of the Tunisian reality, and in its production of solutions for that reality (France 24 Arabic, 2017). 
The final argument pertains to priorities within the Tunisian context. Critics of the inheritance law suggested that the law is a distraction from the pressing economic problems which are burdening the Tunisian state, and therefore is not a priority ('Așādī 2018; Harmāsī 2018; France 24 Arabic 2017; Sayyid 2018). However, the definition of the lack of priority requires further examination. Things could go in parallel, and priority does not mean other agendas and changes cannot be catered for as well; yet a point could be made that the divisions which this conflict will start would split an already a fragile state.

Analysis of the Arguments on Equal Inheritance

Several points should be noted with regard to the report and the subsequent arguments it produced.

Firstly, the debate is no longer between religious arguments versus non-religious, or secular arguments, as several members of Ennahdha party, though a minority, were for equal inheritance, and several leftist and liberals were against the law. The debate was thus largely about the individual, the process of individualization and pluralism within society. For the individual, the question is how to provide rights and equality without undermining social structures (e.g., the family) that some consider as salient for the functioning of the society. For pluralism the question is, how would one allow choices for different groups, without those groups being reduced to a traditionalist/westernized binary. In Tunisia, there is a group that is against the new law and worries about the family structure, but not because they live in the past or because they are Islamists. The former Tunisian President Munsif Marzouki (al-Munșif al-Marzūqī) himself also had concerns about the priority of this reform. On the other side, there is a group which wants gender equality not because they are fascinated with the West, but because they believe pragmatically in its virtue. Lamā Abū 'Ūda (2017) rightly criticized the phobia against this legal transplant in the Arab world, while this is a common practice worldwide. In the same vein, some scholars criticized minimizing the role of inter-civilizational exchange in world history (Salvatore 2016) or the anti-West discourse within the East-West binary of post-colonial studies (Hanafi 2018).

Second, it seems that the rise of Ennahdha and its Islamist counterparts has shifted the debate from whether equal inheritance laws are good policy, to whether equal inheritance laws are religiously legitimate or not. Specifically, the Maquassidī school, which has largely framed the discourse of Ennahdha party, was utilized by the formulators of the Report in their argument for equal 
inheritance. This type of argument, however, was largely represented by the documents issued by those for and against the law, and did not present itself in the public debate occurring on television and through other media portals. However, this decreasingly polarized scene, regardless of intent, has certain promising signs indicating its occurrence, but has surely not matured yet.

The Arab uprisings and the emergence of reflection on the civil state generated some social demand in ijtihäd, exactly as happened in the European context when society pushed the Church to change, and in this context, religious arguments and reasoning within religious sciences was essential in the production and legitimization of policies and political acts. Religion, in this context, adds an extra-dimension to social debates, and makes them more complex, while still maintaining a space in which difference is tolerated and in which every side can provide input.

Third, legal arguments were also shared by both sides, with each attempting to explore the constitution, local legislation, and international law in order to demonstrate why their perspective on equal inheritance is the correct one. However, the official documents issued by the Committee and by Ennahdha show a clear discrepancy. The committee issued an extensive report in which all the arguments were laid out, with references and in a structured manner, whereas Ennahdha issued a one-page statement in which it makes demands, with little to no argumentation. This showed Ennahdha to be far more dogmatic in its official publication than the Committee, and as such put it in a weaker position in this regard.

Fourth, law opponents appealed to parliamentary voting rather than taking a purely textual perspective, and explicitly stated that the people should be allowed to choose whatever they see fit in their governance. This appeal notes an essential transformation in the movement from an ideological dogmatic movement, which views reality in terms of absolutist black-and-white claims, to one which is capable of playing the political game, granting concessions to maintain local peace and stability, and playing the right card to promote its commitment to its foundational principles and defending political cooperation.

Fifth, an analysis of the public statements of the law's proponents shows a conglomeration of arguments, not all of which fulfill Cooke's criteria for nonauthoritarianism and some degree of identity politics persist for several actors, decreasingly for law opponents though. It has been stated, for example, by several civil rights actors, that gender equality is an absolute value, and as such, should be enforced regardless of whether the society itself wants it or not. In this light, it is viewed like the abolition of slavery or the banning of racism and 
racial segregation, but these do not touch the religious identity of the nation like the case of the inheritance does. Similarly, a large majority of individuals surveyed ${ }^{10}$ who were against the law, stated that inheritance laws lie within the realm of Islamic absolutes, and if the government interferes in it, it is becoming anti-religious, or, to say the least, less religious (al-Jazeera Live 2017; al-Nahar TV 2018; France 24 Arabic 2016; Ḥamrāwī 2017; Ten TV 2018). A middle position was expressed by Ennahdha officially later on. It stated that while it does stand against the law of equal inheritance, and considers it antithetical to Islam, the people have a right to determine whether they wish to choose Islamic inheritance laws or equal inheritance laws. This transfer of the debate from the realm of absolutes to the realm of contention allows both sides to make arguments. If the argument moves from absolutism itself, then a realm of mutual dialogue can be created, which could facilitate the creation of the Habermasian public sphere. This will lead to decreasing polarization and identity politics within the Tunisian political arena. For instance, while the idea of the referendum which comes into play as a secular means by which to navigate the religious tendencies of the population, it may also provoke the public to devolve into populist majoritarianism, and may also provide an honorable solution as long as the rational arguments and depolarizing powers remain present, vocal, and active.

Sixth, the idea of choice was another point of contention in the debate. The ontological and teleological superiority of gender equality is shown through the law itself, which was viewed as "contradicting the norms of Tunisian society." Throughout the debate over the legislation, it has been stated that while the will of the owner can overrule the law, however, in the case no preference is made clear, the inheritance is split equally between heirs, and as such the mainstream Islamic law will not be observed.

Seventh, the diversity of the actors on the political scene in Tunisia is a remarkable example in the Arab world. The line between academics and political activists is blurred. Many of the entries analyzed, whether from Facebook, radio, articles, interviews, public lectures, television, or personal blogs, were formulated by academics who currently teach in universities. Those very academics were also present on the streets when the people were protesting, which

10 Hirmāsī (2018) argues that the recent publications of the Situation of Religion in Tunisia of 2015 and from 2011 to 2015 support that. According to "The Religious Situation in Tunisia 2015," $66 \%$ of the Tunisian people reject the idea of equality in inheritance. In "The Religious Situation in Tunisia 2011-2015" report, $64.7 \%$ of the Tunisian people reject the idea of equality in inheritance, $7.27 \%$ are in favour of it, and $6.7 \%$ considered it a matter of freedom; $58 \%$ of women rejected the idea of equality in inheritance, compared with $67.1 \%$ of rejection among men. 
signifies the importance of their role in the Tunisian scene. ${ }^{11}$ The social impact of the research provided by those academics, and their role in the formulation of public awareness, is substantial and important. However, a distinction does arise between the academics who were for the law, who are more in touch with governmental institutions and the political elite, and the academics supporting Islamic inheritance, who seem to be more connected with the masses. This observation is further supported by an analysis of the attendance of demonstrations, with pro-law demonstrations mostly attended by activists, while the opponents drew larger and diverse audiences. These demonstrators accused Essebsi of walking in Bourguiba's footsteps (i.e., muted top-down secularization). Furthermore, in the content analysis of the debate, it is interesting that academics and public intellectuals have been involved from the beginning in the public discourse. The very report issued by the Committee was mostly written by academics, then it was responded to by al-Zaytūna and many political and academic figures. After that, the people took to the streets, and the public debate began to crystallize. Ennahdha chose first not to give a position, reflecting some divergence within the movement, and only after a few months, an official statement was issued by the movement, based on numerous internal meetings. This statement issued by the movement was much shorter and less nuanced than the report of the Committee, and while rejecting the law, provided a potential acceptance through a referendum, considered as a means of arbitration in the political arena.

This mapping of the inheritance debate has shown three sets of arguments: jurisprudential/textual, sociological, and legal. While the position of the proponents of gender equality are based primarily on legal, then sociological, then jurisprudential/textual arguments, opponents use the textual, then legal, and finally sociological arguments. For example, the weakness of the sociological argument of the latter is clear when they rely on the idea that there is still a gendered division of labor within the family, in which the man bears the major financial burden of the family helping parents and siblings in case of distress, as they did not provide neither statistics nor empirical evidence. Yet, the discussion occurring in Tunisia uses common language (interpreting the religious text, among other things), which allows for the reduction of authoritarian tendencies, and the reduction of longstanding polarization through means of dialogue. We have witnessed less tension than aptly described by Khaled

This observation is based on interviews with some activists and scholars. 
Abou El Fadl (1997) between the authoritative and the authoritarian in Islamic discourse, i.e., the process by which the authoritative is used to produce the authoritarian. In the same vein, Alexandre Caeiro (2019) argues, based on his study of Qatar's muftīs, that some religious figures have started drawing on "the textual resources of the Islamic tradition and to affirm some of its key commitments while adopting modern sociological ideas and adjusting to emerging moral orders."

Appeals to texts and values, whether religious or universalist, is a more tricky proposition, as these arguments tend to fall in the realm of absolutist authoritarianism on both ends of the spectrum. However, the debate in Tunisia still needs to be grounded more in the socio-political reality, which might reveal the way through which Tunisia can find its way to a better future, avoiding deep conflict with its historical heritage and zeitgeist. History and context, which facilitate ijtihād and mașlaha, were used by most actors to justify their reasoning, and this embodies non-authoritarian conceptions of knowledge and justification, yet this was not sufficiently deployed, thus making the authoritarian tendencies linger nonetheless. ${ }^{12}$ A voluntary implementation of inheritance regimes (a sort of a legal pluralism) may allow all to mediate their tendencies, and practice whatever they believe to be just, regardless of whether others agree with them or not. These legal arrangements may enable fair litigation and feed the construction of a salient 'rights-versusrites binary' in law and politics in the complex reality of the political constitution of religion and the religious constitution of politics (see for the case of Malaysia: Moustafa 2018). It is not surprising that Tunisia has become a laboratory for such relatively healthy debate and to speak with Karim Sadek (2012) a laboratory to "unleash the emancipatory potentials of Islamic politics while curbing its authoritarian potentials," thanks to the dissident Islamic thought of Rached Ghanouchi (Rāshid al-Ghannūshī). It is useful to compare the Tunisian

12 Wael Hallaq (1984) notes that ijtihād was viewed by scholars of the four schools of figh as being incumbent upon the ruler of a community, or upon an advisor of the ruler. The incidents which take place in a socio-political context, and within certain customs of peoples ( $\left.a^{\prime} r \bar{f} f\right)$ create the need for a jurisprudential process which accounts for the changing reality. Hence, history and context are not a newly suggested introduction to ijtihäd, but one which was part and parcel of the production of jurisprudence throughout Islamic history. In a more modern context, Muhammad Zaman (2012) has argued that ijtihäd is constantly being reworked within modernist, Salafī, and Deobandi schools, and has in many cases been transformed into collective $i j t i h \bar{a} d$, in cooperation with specialists, taking into consideration both necessity (ḍaüra) and interest (mașlaḥa); and while some like Tariq Ramadan argues for a radical reform, rather than simpler ijtihäd without or outside the scope of the four schools of figh, Zaman argues that ijtihäd in its currently contested forms is sufficient to answer the questions of the modern world. 
debate of inheritance law to the statement of al-Azhar, being so unreconciliatory with those who are in favor of equality in inheritance, considering them apostates.

In this article, we use Maeve Cooke's qualification of what constitutes a nonauthoritarian practical reasoning, necessary for a public debate. This framework is quite different from Jürgen Habermas' post-metaphysical-secularistmodel that unnecessarily restricts the access of religious community to the formal deliberation of public reason. His post-metaphysical model internalized the particular historical and cultural traditions on the basis of which the secular basis of political authority was once regarded as justified (Cooke 2007, 234; Asad 2003). In the processes of revolution and counter-revolution in the Arab world, and in debates identifying democratic forces, attention is rarely given to the elite's practical reasoning, with the emphasis almost exclusively being on the secularization paradigm. Secular forces were seen as systematically immune to the authoritarian practical reasoning, while the Islamic movements by definition operate within such frameworks. Of course, this is simplistic, and needs to be scrutinized, as authoritarian citizens can be found among both these elite formations.

The use of the Maeve Cooke framework in studying the Tunisian debate helped us to deconstruct the binary logic of the religious juxtaposed to the secular which situates people as inherently inferior or different, creating what Nancy Fraser called a 'field of multiple, debinarized, fluid, ever-shifting differences' (Fraser 1997). This debate is part of the ongoing process of realization of Alex Honneth's socio-political principle of recognition (Honneth 1996). Through dialogue, proponents and opponents of the inheritance law start to recognize the needs of each other without applying the exclusionary labels of 'Western' or 'traditionalist'. Any denial of religious groups, women and men, as legitimate voices in the public debate is an act of misrecognition and would reinforce identity politics. In the same vein, those who believe in the virtue of the individual and individualism in a changing Tunisian society are also legitimate grassroots voices (Hénia 2015) that cannot be reduced to foreign influence and westernized taste.

\section{Bibliography}

Abou El Fadl, Khaled. 1997. The Authoritative and Authoritarian in Islamic Discourses. Austin, TX: Dar Taiba.

Abū 'Ūda, Lamā. 2017. "Man Yaktarith lil-QQ̄nūn al-Islāmī” (Who Cares About Islamic Legislation). Al-Jumhūriyya, 5 July 2017. www.aljumhuriya.net/ar/38368. 
Aduna, Danna Patricia S. 2015. "The Reconciliation of Religious and Secular Reasons as a Form of Epistemic Openness: Insights From Examples in the Philippines." The Heythrop Journal 56 (3): 441-53. Doi: 10.111//heyj.12255.

Agrama, Hussein Ali. 2010. "Secularism, Sovereignty, Indeterminacy: Is Egypt a Secular or a Religious State?" Comparative Studies in Society and History $5^{2}$ (3): 495-523. Doi: 10.1017/Soo10417510000289.

Aḥmar, Mūldī al-. 2014. "Introduction.” In Al-Thawra al-Tūnisiyya al-Qādiḥ al-Mahallī taḥt Mijhar al-Ulūm al-Insāniyya (The Tunisian Revolution: The Local Trigger under the Microscope of the Social Sciences), 23-42. Beirut: al-Markaz al-'Arabī lil-Abḥāth wa-Dirāsāt al-Siyāsāt.

al-Jazeera Live. 2017. “Ra’y al-Shāri' al-Tūnisī haw ijrā’ Murāja āt Qānūniyya Tusāwī bayn al-Mar’a wa-l-Rajul fī l-Mīrāth wa-l-Zawāj min Ajnabi” (Tunisian Street Opinions on Conducting Legal Revisions to Give Women and Men an Equal Status in Inheritance and Marriage to a non-Muslim). www.youtube.com/watch?v=XkkmOaiRlA8.

al-Nahar TV. 2018. "Niqāsh 'alā l-Mubāshir: Tūnis Tattajih li-Iqrār al-Musāwāt fī al-Irth bayn al-Rajul wa-l-Mar`a. Ayy Ta’thīr 'alā l-Jazāir?” (Discussion: Tunisia Is Moving towards Establishing Equality in Inheritance between Men and Women. Any Effect on Algeria?). www.youtube.com/watch?v=zKnUxURJQcc.

Asad, Talal. 2003. Formations of the Secular: Christianity, Islam, Modernity. Stanford, CA: Stanford University Press.

'Aṣādī, Tāriq al-. 2018. “'Abd al-Lațîf al-Makkī li-'Ākhir Khabar Ūnlāyn': Hunālik mā Ahamm min Taqrīr Lajnat al-Ḥurriyyāt ... Wa-Hadhihī Faḥwā Risālat al-Nahdha ilā Rảīs al-Jumhūriyya" ('Abd al-Lațîf al-Makkī to 'Ākhir Khabar Online': There are more important matters than the report of the Freedoms Committee ... This is the essence of the message of the Ennahdha Party to the President of the Republic). Ākhir Khabar Online, August 12, 2018. www.akherkhabaronline.com/ar- عبد اعبد

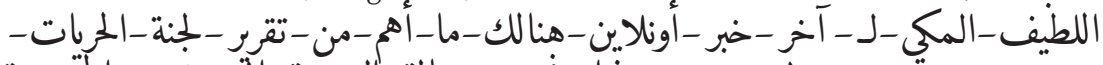

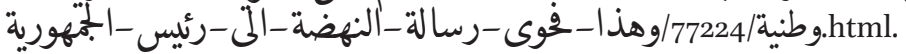

в вс News. 2018. "Hal Sayumarrar Qānūn al-Musāwāt fî l-Irth bayn al-Rajul wa-l-Mar’a fī Tūnis?" (Will the Law on Equal Inheritance between Men and Women Be Passed in Tunisia?). www.youtube.com/watch?v=2ifEDFzoJk8.

Bin Ḥasan, Bashīr. 2016. "Al-Ṣafḥa al-Rasmiyya lil-Shaykh Bashīr Bin Hasan" (The Official Page of Shaykh Bashīr Bin Hassan). May 16, 2016. www.facebook.com/ Bachire.Ben.Hsan/photos/a.201786733168642.61112.198003930213589/1314406408 $573330 /$ ?type $=3 \&$ theater.

Bū'ushba, Tawfīq. 2018. "Al-Mukhtașs fī l-Qānūn Tawfĩq Bū'ushba li-l-Shurūq': li-Hadhih al-Asbāb U'āriḍ Taqrīr Bushrā lil-Ḥurriyyāt" (Specialist in public law Tawfīq Bū'ushba to "al-Shurūq": For these reasons I oppose the report of the Freedoms Committee). Al-Shurūq. August 11, 2018. www.alchourouk.com/article/- المختص

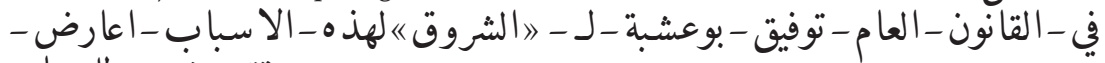
تقريشرى -للحريات. 
Caeiro, Alexandre. 2019. "The Politics of Family Cohesion in the Gulf: Islamic Authority, New Media, and the Logic of the Modern Rentier State." Arabian Humanities 10 (2018): 1-29. Doi: 10.4000/cy.3762.

Charrad, Mounira M. 2001. States and Women's Rights: The Making of Postcolonial Tunisia, Algeria, and Morocco. Berkeley: University of California Press.

Committee on Individual Liberties and Equality. n.d. "Membres-Colibe." Accessed November 15, 2018. https://colibe.org/membres/?lang=en.

Cooke, Maeve. 2005. "Avoiding Authoritarianism: On the Problem of Justification in Contemporary Critical Social Theory." International Journal of Philosophical Studies 13 (3):379-404. Doi: 10.1080/o9672550500169182.

Cooke, Maeve. 2006. "Salvaging and Secularizing the Semantic Contents of Religion: The Limitations of Habermas's Postmetaphysical Proposal." International Journal for Philosophy of Religion 6o (1): 187-207. Doi: 10.1007/s11153-006-00o6-5.

Cooke, Maeve. 2007. "A Secular State for a Postsecular Society? Postmetaphysical Political Theory and the Place of Religion." Constellations 14 (2): 224-38.

al-Ḍaīif, Rashīd. 2012. Taștafil Mìrül Strīb (Meryl Streep Can Suit Herself). Beirut: al-Sāqī. Dworkin, Ronald. 1978. Taking Rights Seriously: With a New Appendix, a Response to Critics. Fifth Printing edition. Cambridge, MA: Harvard University Press.

Dworkin, Ronald. 1985. A Matter of Principle. Cambridge, MA: Harvard University Press. Ennahdha Party. 2018. "Al-Bayān al-Khitāmī lil-Dawra 21 li-Majlis Shūrā Harakat al-Nahda" (Final statement of the 21st session of the Shūrā Council of the Ennahdha Movement). Harakat al-Nahda. August 26, 2018. www.ennahdha.tn/

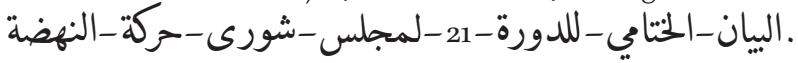

Fadel, Mohammad. 2007. "Public Reason as a Strategy for Principled Reconciliation: The Case of Islamic Law and International Human Rights." Chicago Journal of International Law 8 (1): 1-20. https://papers.ssrn.com/abstract=981777.

FIDH. 2014. "Tunisia: CEDAW Reservations Officially Withdrawn." International Federation for Human Rights. April 29, 2014. www.fidh.org/en/region/north-africamiddle-east/tunisia/15372-tunisia-cedaw-reservations-officially-withdrawn.

France 24 Arabic. 2016. "Tūnis: Jadal Ḥawl Mubādara Tashrīiyya Tad'ū lil-Musāwāt bayn al-Rajul wa-l-Mar’a fī l-Mīrāth" (Tunisia: Debate over Legislative Initiative Calling for Equality between Men and Women in Inheritance). www.youtube.com/ watch?v=3XA7SB2mqH8.

France 24 Arabic. 2017. "Tūnis: al-Musāwāt bayn al-Rajul wa-l-Mar’a ... al-Sibsī 'alā Khuțā Būrqība?" (Tunisia: Equality between Men and Women ... Sibsi in the Footsteps of Bourguiba?) www.youtube.com/watch?v=da22RM3NGbM.

Fraser, Nancy. 1997. Justice Interruptus: Critical Reflections on the "Postsocialist" Condition. New York: Routledge.

Grewal, Sharan. 2018. "Can Tunisia Find a Compromise on Equal Inheritance?" Brookings (blog). September 25, 2018. www.brookings.edu/blog/order-from-chaos/2018/og/25/ can-tunisia-find-a-compromise-on-equal-inheritance/. 
Habermas, Jurgen. 2008. Between Naturalism and Religion. Cambridge: Polity Press.

Hallaq, Wael B. 1984. "Was the Gate of Ijtihad Closed?" International Journal of Middle East Studies 16 (1): 3-41.

al-Ḥamrāwī, Usāma. 2017. “'Abd al-Lațîf al-Makkī li-'Ākhir Khabar Ūnlāyn': 'Mā Jāa 'alā Lisān Ra'īs al-Jumhūriyya bi-Khuṣūṣ al-Tanāṣuf fī l-Mīrāth Amr Khațīr” ('Abd alLațîf al-Makkī to 'Ākhir Khabar Online': 'What the president said about inheritance is dangerous'). Ākhir Khabar Online, August 13, 2017. www.akherkhabaronline.com/

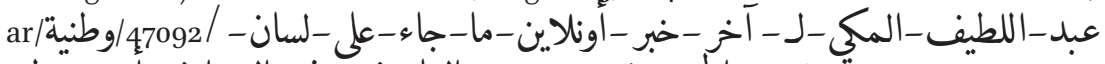

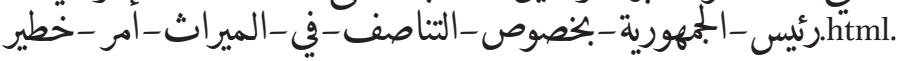

Hanafi, Sari. 2018. "Postcolonialism's After-Life in the Arab World: Toward a PostAuthoritarian Approach." In Routledge Handbook of South-South Relations, edited by Elena Fiddian-Qasmiyeh and Patricia Daley, 76-85. London: Routledge.

Harmāsī, 'Abd al-Lațîf. 2012. Fì l-Mawrūth al-Dīn̄i al-Islāmī: Qirā̉a Sūsyūlūjìyya Tārīkhiyya (On the Islamic Religious Heritage: A Sociological-Historical Reading). Cairo: Dār al-Tanwīr.

Harmāsī, 'Abd al-Lațīf. 2018. Al-Mujtama' wa-l-Islām wa-l-Nukhab al-Ișlāhìyya fi Tūnis wa-l-Jazāîr: Dirāsa Muqārana min Manzūū Ilm al-Ijtimā’ al-Tārīkhī (Society, Islam and Reformist Elites in Tunisia and Algeria: A Comparative Study from the Perspective of Historical Sociology). Beirut: al-Markaz al-'Arabī lil-Abhāth waDirāsāt al-Siyāsāt.

Hénia, Abdelhamid. 2015. Le Fère, Le Sujet et Le Citoyen: Dynamique Du Statut Politique de l'Individu En Tunisie. Tunis: L'Or du temps. www.hssma.org/publication.cfm? $\mathrm{id}=279$.

Honneth, Axel. 1996. The Struggle for Recognition: The Moral Grammar of Social Conflicts. Translated by Joel Anderson. Cambridge, MA: The Miт Press.

'Īd, Laylā. 2017. "Mūrū: Wuḍūh al-Qửān Mana'a Būrqība min Musāwāt al-Mīrāth." Al-Nahār Ūnlāyn. August_29, 2017. www.ennaharonline.com/-مورو-وضوح" القرآن-منع -بورقيبة-من -مساواة.

'Īsā, Luṭ̂i. 2018. "Sufi Experiences in Tunisia." In Al-Hāla al-Dīniyya fì Tūnis 2011-2015 (The Religious Situation in Tunisia 2011-2015). Vol. 3. Rabat: Mu’minūn bilā Hudūd. Kandiyoti, Deniz. 2004. "Contesting Patriarchy-as-Governance: Lessons from YouthLed Activism." OpenDemocracy. March 7, 2004. www.opendemocracy.net/5050/ deniz-kandiyoti/contesting-patriarchy-as-governance-lessons-from-youth-led-activism.

Kapitalis Anbā’ Tūnis. 2018. "Ḥawl al-Musāwāt fĩ l-Irth: Halaqa Jadīda fī Silsilat Makāsib al-Mar’a al-Tūnisiyya” (On equality in inheritance: a new chapter in the Tunisian women's gains series). Kapitalis Anbä’ Tünis. August 15, 2018. www.kapitalis.com/ anbaa-tounes/2018/08/15/142957/.

Mahmood, Saba. 2011. Politics of Piety: The Islamic Revival and the Feminist Subject. Princeton, NJ: Princeton University Press. 
McCarthy, Rory. 2014. "Re-Thinking Secularism in Post-Independence Tunisia." The Journal of North African Studies 19 (5): 733-50. Doi: 10.1080/13629387.2014.917585.

MediıTV. 2018. "Tūnis: Masīra Nisa'iyya Ḥāshida lil-Muṭālaba bi-l-Musāwāt fī l-Irth" (Tunisia: Massive Women's March to Demand Equal Inheritance). www.youtube. com/watch?v=8Jl8Rsa45SI.

Mosaique FM. 2018. "Al-Umam al-Muttaḥida Turaḥhị bi-l-Mubādara fī Majāl alMusāwāt fī l-Mīrāth fī Tūnis" (The United Nations welcomes the initiative in the area of equal inheritance in Tunisia). Mosaique FM. August 15, 2018. www.mosaique

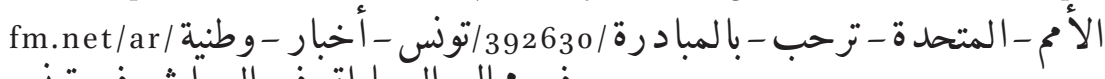

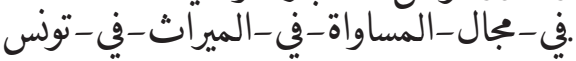

Moustafa, Tamir. 2018. Constituting Religion: Islam, Liberal Rights, and the Malaysian State. Cambridge: Cambridge University Press.

Nyhagen, Line. 2017. "The Lived Religion Approach in the Sociology of Religion and Its Implications for Secular Feminist Analyses of Religion." Social Compass 64 (4):495-511.

Rașîf 22. 2017. "Iftā’ Tūnis Yaḥsim al-Jadal wa-Yu’ayyid Musāwāt al-Mar’a ma' alRajul fì l-Mīrāth" (Iftā’ Tunisia resolves controversy and supports women's equality with men in inheritance). Rașif 22. August 15, 2017. https://raseef22.com/

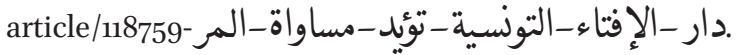

Rawls, John. 1993. Political Liberäism. New York: Columbia University Press.

Reuters. 2018. "Tunisian President Proposes Inheritance Equality for Women, With ..." Reuters, August 13, 2018. www.reuters.com/article/us-tunisia-women/tunisianpresident-proposes-inheritance-equality-for-women-with-exceptions-idUSKBNiKYiGE.

Sadek, Karim Sadek. 2012. "Islamic Democracy: The Struggle for and Limits of Recognition." Ph.D. diss., Georgetown University.

Salvatore, Armando. 2016. The Sociology of Islam: Knowledge, Power and Civility. Chichester: Wiley.

Sayyid, Rị̣wān al-. 2018. "Al-Shar'iyya al-Islāmiyya fỉ l-Mujtama' wa-l-Dawla" (Islamic legitimacy in society and the state). al-Sharq al-Awsat, August 24, 2018. https://

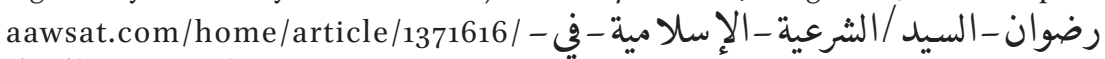
المجتمع -والدولة.

Scott, Joan Wallach. 2017. Sex and Secularism. Princeton, NJ: Princeton University Press. Sharaf al-Dīn, Kārim. 2017. "Mādhā Qāl Mustashār al-Ghannūshī 'an al-Musāwāt fī al-Mīrāth?" (What did Ghannouchi's advisor say about equality in inheritance?). Arabi21. September 26, 2017. https://arabi21.com/story/103686o/.

Sharāra Bayḍūn, Ghazza. 2007. Al-Rujūla wa-Taghyīr Aḥwāl al-Nisā’ (Manhood and Changing Women's Conditions). Beirut: al-Markaz al-Thaqāfì al-'Arabī.

Sky News Arabia. 2018. "Tūnis.. Da'awāt lil-Istiftā’ fì Qadiyyat al-Musāwāt fī al-Irth." (Tunisia Calls for a referendum on the issue of equality in inheritance). Sky News Arabia, August 17, 2018. www.skynewsarabia.com/middle-east/1174232. 
Social Institutions and Gender Index. 2014. "Tunisia | Gender Index." Social Institutions and Gender Index. www.genderindex.org/country/tunisia/\#_ftn1.

Ten TV. 2018. "Ra'y 'Āmm —-Mushādda bayna I'lāmiyya Tūnisiyya wa-Ālim Azharī hawl al-Musāwāt fĩ l-Irth bi-Tūnis” (Public Opinion-An Argument between a Tunisian Journalist and an Azhari Scholar on Equality in Inheritance in Tunisia). www.youtube.com/watch?v=BDM8oEkıDzk.

Walhof, Darren R. 2013. "Habermas, Same-Sex Marriage and the Problem of Religion in Public Life." Philosophy and Social Criticism 3 (39): 225-42.

Zaman, Muhammad Qasim. 2012. Modern Islamic Thought in a Radical Age: Religious Authority and Internal Criticism. Cambridge: Cambridge University Press. 